\title{
SDGs and Home Economics: Global Priorities, Local Solutions
}

\author{
Donna Pendergast \\ School of Education and Professional Studies, Griffith University \\ 176 Messines Ridge Road \\ Mount Gravatt, QLD, 4122, Australia \\ d.pendergast@griffith.edu.au
}

\begin{abstract}
The Sustainable Development Goals (SDGs) is a set of seventeen aspirational global goals that envisage a world transformed from today where poverty and gender inequality no longer exist; where good healthcare and education are available for all; and where economic growth no longer harms the environment. The ambition is huge and every country in the world falls short on more than half of the 17 SDGs. As the agenda gains momentum, finding ways to activate change is at the core of success. It is in this context that home economics has the potential to make a contribution. This paper presents an exploration of the role of home economics to accelerate progress towards achieving selected SDGs by 2030.
\end{abstract}

Keywords - sustainable development goals; home economics; change; intentional

\section{THE SUSTAINABLE DEVELOPMENT}

The eight Millennium Development Goals (MDGs) were agreed by world leaders at a United Nations summit in 2000, setting eight targets to achieve by 2015 (United Nations General Assembly, 2000). The strategy typically involved developing countries committing to improvements in policy, accountability and governance while developed countries pledged to provide resources.

Building on and expanding the MDGs since the expiration of the commitment period in 2015, the Sustainable Development Goals (SDGs) relate to the period from 2015 to 2030. Officially known as Transforming our world: the 2030 Agenda for Sustainable Development (United Nations, 2015), the SDGs are a set of seventeen aspirational global goals with 169 targets between them. The agenda sets a deliberative approach involving 194 member states. Compared to the MDGs, the SDGs are universal, more ambitious and comprehensive. They provide a focus for all countries, whether developed or developing, which is a shift from the underpinning approach of the MDGs. The SDGs envisage a world transformed where poverty and gender inequality no longer exist; where good healthcare and education are available for all; and where economic growth no longer harms the environment. The ambition is huge and every country in the world falls short on more than half of the 17 SDGs while a quarter fall short on all 17 of the goals. The SDGs courageously set specific and measurable targets in relation to the 17 goals. As the SDG agenda gains momentum, finding ways to activate change is at the core of success. Many of the goals are applicable to the field of home economics either directly or indirectly. According to the IFHE 2008 Position Paper, home economics is "a field of study and a profession, situated in the human sciences that draws from a range of disciplines to achieve optimal and sustainable living for individuals, families and communities" (International Federation for Home Economics [IFHE], 2008 p.1). It is clear from this internationally agreed definition that home economics and the SDGs are aligned in intent and aspiration. There is an interesting alignment between the MDGs and the SDGs and how they relate to each other based around the six principles of: dignity, people, planet, partnership, justice and prosperity (The Guardian, 2015). This information is presented in Table 1, which also reveals that the principles of justice and prosperity were not included in the MDGs. Table 1 also identifies five SDGs that have been selected by the International Federation for Home Economics as particular foci for the work of the profession, alongside six SDGs identified by Pendergast (2017) as a priority list for the profession. Both chose SDG 3 Ensure healthy lives and promote wellbeing for all at all ages; SDG 5 Achieve gender equality and empower all women and girls; and SDG 12 Ensure sustainable consumption and production patterns. In order to explore the ways in which the home economics profession can accelerate progress towards achieving the SDGs, this paper now positions the home economics profession at this time in its development as a field, with a particular focus on home economics literacy as a way of understanding the profession.

\section{HOME ECONOMICS LITERACY}

Since March 21st, 1982 IFHE has continued to recognise March 21sth each year as World Home Economics Day (WHED, IFHE, 2015). The purpose of the day is to publicise and promote IFHE and the Home Economics Profession. The themes for recent celebratory days all have 'home economics literacy' in common:

- 2015: Home Economics Literacy: Skills for Families and Consumers-Food Literacy and Environmental Literacy

- 2016: Home Economics Literacy: Skills for Families and Consumers 
by IFHE (2107) AND PANDERGAST (2017)

\begin{tabular}{|c|c|c|c|}
\hline MDG 2000-2015 & Focus area & \multicolumn{2}{|c|}{ SDG 2015-2030 } \\
\hline $\begin{array}{l}\text { 1. Eradicate Extreme Hunger } \\
\text { 3. Promote Gender Equality and } \\
\text { Empower Women }\end{array}$ & $\begin{array}{l}\text { Dignity } \\
\text { End poverty and fight inequality }\end{array}$ & & $\begin{array}{l}\text { End poverty in all its forms everywhere } \\
\text { Achieve gender equality and empower all women and girls }\end{array}$ \\
\hline $\begin{array}{l}\text { 2. Achieve Universal Primary } \\
\text { Education } \\
\text { 4. Reduce Child Mortality } \\
\text { 5. Improve Maternal Health } \\
\text { 6. Combat HIV AIDS Malaria and } \\
\text { Other Diseases }\end{array}$ & $\begin{array}{l}\text { People } \\
\text { Ensure healthy lives, knowledge and } \\
\text { the inclusion of women and children }\end{array}$ & $\begin{array}{l}2 \# \\
* 3 \# \\
4 \#\end{array}$ & $\begin{array}{l}\text { End hunger, achieve food security and improved nutrition and promote } \\
\text { sustainable agriculture } \\
\text { Ensure healthy lives and promote wellbeing for all at all ages } \\
\text { Ensure inclusive and quality education for all and promote lifelong learning }\end{array}$ \\
\hline $\begin{array}{l}\text { 7. Ensure Environmental } \\
\text { Sustainability }\end{array}$ & $\begin{array}{l}\text { Planet } \\
\text { Protect our ecosystem, for all societies } \\
\text { and for our children }\end{array}$ & $\begin{array}{l}* 6 \\
* 12 \# \\
13 \\
14 \\
15\end{array}$ & $\begin{array}{l}\text { Ensure access to water and sanitation for all } \\
\text { Ensure sustainable consumption and production patterns } \\
\text { Take urgent action to combat climate change and its impacts } \\
\text { Conserve and sustainably use the oceans, seas and marine resources } \\
\text { Sustainably manage forests, combat desertification, halt and reverse land } \\
\text { degradation, halt biodiversity loss }\end{array}$ \\
\hline \multirow[t]{3}{*}{$\begin{array}{l}\text { 8. Develop a Global Partnership for } \\
\text { Development }\end{array}$} & $\begin{array}{l}\text { Partnership } \\
\text { Catalyze global solidarity for } \\
\text { sustainable development }\end{array}$ & $17 \#$ & Revitalise the global partnership for sustainable development \\
\hline & $\begin{array}{l}\text { Justice } \\
\text { Promote safe and peaceful societies and } \\
\text { strong institutions }\end{array}$ & 16 & Promote just, peaceful and inclusive societies \\
\hline & $\begin{array}{l}\text { Prosperity } \\
\text { Grow a strong, inclusive and } \\
\text { transformative economy }\end{array}$ & $\begin{array}{l}7 \\
8 \\
9 \\
10 \\
11\end{array}$ & $\begin{array}{l}\text { Ensure access to affordable, reliable, sustainable and modern energy for all } \\
\text { Promote inclusive and sustainable economic growth, employment and decent } \\
\text { work for all } \\
\text { Build resilient infrastructure, promote sustainable industrialisation and foster } \\
\text { innovation } \\
\text { Reduce inequality within and among countries } \\
\text { Make cities inclusive, safe, resilient and sustainable }\end{array}$ \\
\hline
\end{tabular}

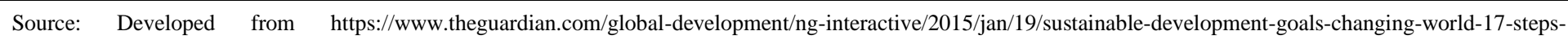
interactive

Key: $\quad *$ Priorities for the home economics profession identified by IFHE (2017): 1, 3, 5, 6, 12

\# Priorities for the home economics profession identified by Pendergast (2017): 2, 3, 4, 5, 12, 17

- 2017: Home Economics Literacy-Empowering for Healthy and Sustainable Lifestyles

What do we mean by 'literacy'? This concept, as related to home economics, has been explored in other places, see for example Pendergast $(2015,2017)$. In both instances the point has been made that definitions of literacy as a learning tool have progressed over recent decades. Smith (2009, p.55) for example suggests " $[\mathrm{G}]$ eneral literacy has broadened to include negotiating, critical thinking and decision-making skills" and there are many terms that have been added to the concept of literacy to apply it to fields. Nutbeam (2000) identified three progressive levels of health literacy: basic/functional, communicative/interactive and critical. Functional health literacy is the use of basic literacy skills to function successfully in everyday situations, while interactive health literacy expands these handling information skills with social and personal skills applied to new and more complex situations. Critical health health literacy as its name suggests, is the development of further cognitive skills for critical analysis, thus leading to self-efficacy and empowerment towards individual and collective actions. These aspects usefully classify health literacy in terms of what it enables individuals to do (Freebody \& Luke, 1990) and how it can improve capacity for social action. Literacy is thus an enabler and a capacity.

The IFHE Position Statement - Home economics in the 21 st Century (IFHE, 2008) provides the most definitive and current statement about home economics at this time, stating that home economics is a "field of study and a profession, situated in the human sciences that draws from a range of disciplines to achieve optimal and sustainable living for individuals, families and communities" with content that "draws from multiple disciplines, synthesizing these through interdisciplinary and transdisciplinary inquiry" (p.1). Importantly, the Position Statements clearly articulates that home economics has four areas of practice:

- $\quad$ as an academic discipline to educate new scholars, to conduct research and to create new knowledge and ways of thinking for professionals and for society

- $\quad$ as an arena for everyday living in households, families and communities for developing human growth potential and human necessities or basic needs to be met 
- as a curriculum area that facilitates students to discover and further develop their own resources and capabilities to be used in their personal life, by directing their professional decisions and actions or preparing them for life

- as a societal arena to influence and develop policy to advocate for individuals, families and communities to achieve empowerment and wellbeing, to utilise transformative practices, and to facilitate sustainable futures.

And it has three essential dimensions:

- a focus on fundamental needs and practical concerns of individuals and family in everyday life and their importance both at the individual and near community levels, and also at societal and global levels so that wellbeing can be enhanced in an ever changing and ever challenging environment;

- the integration of knowledge, processes and practical skills from multiple disciplines synthesised through interdisciplinary and transdisciplinary inquiry and pertinent paradigms; and

- demonstrated capacity to take critical/ transformative/ emancipatory action to enhance wellbeing and to advocate for individuals, families and communities at all levels and sectors of society.

The Position Statement further explains that "[E]nsuring the interplay of these dimensions of Home Economics is the basis upon which the profession can be sustained into the future. Because of these attributes, Home Economics is distinctively positioned to collaborate with other professionals" (IFHE, 2008 , p.2). One way of looking at what would comprise the Essential Dimensions and the Areas of Practice is to consider these elements in the context of one aspect of home economics knowledge. An exemplar is presented in Table 2 for the topic of consumer studies.
The relationships between the four areas of practice and the three essential dimensions is the point where home economics practise occurs - that is, in an area and with all essential dimensions in play. It is indeed the case that the field draws from a range of discipline sources and these are often contextually specific.

This can be graphically presented, as represented in Figure 1. HELM - Home Economics Literacy Model. The interplay between the features presents as a kind of warp and weft that together form the pointy end of the field of study we know as home economics. What this point of convergence represents is the presence of all four areas of practice through the three essential dimensions. Without each of these aspects present, it is argued that home economics literacy is not present. Furthermore, this point of convergence provides the space for best practice in the field.



Fig. 1. HELM - Home Economics Literacy Model Source: Pendergast (2015)

TABLE II. EXAMPLE OF ESSENTIAL DIMENSIONS AND THE AREAS OF PRACTICE OF HOME ECONOMICS CONSUMER STUDIES

\begin{tabular}{|l|l|l|l|}
\hline Consumer studies & Needs of individuals \& families & Multidisciplinary integration & Transformative action \\
\hline Academic Discipline & $\begin{array}{l}\text { Identify gaps in food labelling } \\
\text { research }\end{array}$ & $\begin{array}{l}\text { Investigate, graphic design, } \\
\text { nutrition knowledge, branding } \\
\text { conventions }\end{array}$ & $\begin{array}{l}\text { Propose new labelling } \\
\text { conventions to meet the needs of } \\
\text { food decision makers }\end{array}$ \\
\hline Everyday Living & $\begin{array}{l}\text { Selection of household products } \\
\text { and services }\end{array}$ & $\begin{array}{l}\text { Use scientific processes to analyse } \\
\text { product service qualities }\end{array}$ & $\begin{array}{l}\text { Empower individuals to make } \\
\text { decisions about product and } \\
\text { service selection }\end{array}$ \\
\hline Curriculum Area & $\begin{array}{l}\text { Identify consumer rights and } \\
\text { responsibilities as a core learning } \\
\text { area }\end{array}$ & $\begin{array}{l}\text { Incorporate content from a range } \\
\text { of knowledge bases (e.g. finance } \\
\text { and budgeting) }\end{array}$ & $\begin{array}{l}\text { Empower students to exercise } \\
\text { their rights through a practical } \\
\text { application }\end{array}$ \\
\hline Society \& Policy & $\begin{array}{l}\text { Access consumer policy } \\
\text { documents for individuals and } \\
\text { families }\end{array}$ & $\begin{array}{l}\text { Consider the breadth of policies } \\
\text { related to consumer law }\end{array}$ & $\begin{array}{l}\text { Provide advice as a consumer } \\
\text { advocate on a government } \\
\text { committee }\end{array}$ \\
\hline
\end{tabular}


It is no accident that the acronym HELM is employed to represent Home Economics Literacy Model. In boating terms, the helm is a ship's steering mechanism. This acronym can also be regarded as capturing the essence of the steering and future direction for the field of home economics.

It is clear from this internationally agreed definition of the field that home economics and many of the SDGs are aligned in intent and aspiration. According to the IFHE Position Statement-Home economics in the 21st Century (IFHE, 2008), the impact of the home economics profession can be regarded thus:

Home Economics is a vital profession currently enjoying renewed attention in the present era. Our contemporary world is characterised as one of unprecedented transition from industrial to knowledgebased culture and globalised economy, with allencompassing effects on society and culture. The information age is complex, diverse and unpredictable, yet has a strong commitment to retaining those elements of society that are valued, while looking ahead to the imperative of improving the world in which we all live such that sustainable development [author italics] is possible. Herein lies the potential for Home Economics and the reason for renewed attention to the field of study, as this is the key imperative of the profession (IFHE, 2008, p2).

It is pertinent to point out that for almost a decade since this Statement (IFHE, 2008) was launched at the IFHE World Congress there has been a clear articulation of the links between the home economics profession and sustainable development, with the last lines of this quote identifying this as the "key imperative of the profession". Hence, it is undeniably the agenda of the profession to focus on the SDGs.

\section{POTENTIAL OF HOME ECONOMICS TO ACCELERATE SDGS}

The potential role of the home economics profession to accelerate progress towards achieving selected SDGs by 2030 is now explored.
This requires challenging the status quo, encouraging collaboration and innovation. Flagged in the 2008 Position Paper, home economics is poised to engage with first the MDGs and now the SDGs. Enablers and inhibitors to home economics contributing to the SDG agenda are examined and an action plan for building an efficacy base for the profession is proffered. As already noted in this paper, the IFHE (2017) has identified five SDGs for action, while Pendergast (2017) has identified six, with overlaps on three SDGs. This points to the capacity for the field to have considerable impact and to require strategic attention around selected SDGs. This might potentially help shape the key priorities for the profession for the next 15 years. For the purposes of this paper, an example of home economics literacy and the SDG Goal 2 End hunger, achieve food security and improved nutrition and promote sustainable agriculture.

The global demand for food is projected to increase by 2030 by 50 percent compared with the current needs in order to meet the increasing demand of the world's growing population which by then is predicted to be nearly nine billion people (Maggio, Van Criekinge, \& Malingreau, 2015). This growing global population, along with accelerating urbanization and deteriorating natural resources, points to a scenario where there will be more people to feed with less water, land and rural labour (Food and Agriculture Organization [FAO], 2016). Finding a sustainable solution to achieve food security without harming the environment therefore poses a great challenge for the SDG 2 on ending hunger.

The role of home economics is specifically connecting the SDG with the Essential Dimensions and Areas of Practice of the home economics professional practice, as outlined in Table 3.

According to the Dugarova and Gülasan (2017) there are six mega-trends that have the potential to significantly enhance the prospects for the successful achievement of the SDG agenda if they are intentionally managed:

\section{TABLE III. SDG GOAL 2 WITH HOME ECONOMICS STRATEGIES}

\begin{tabular}{|c|c|c|c|c|}
\hline SDG Goal 2 & End hunger, achieve food security and & \multicolumn{3}{|c|}{ Essential Dimensions } \\
\hline Challenge & $\begin{array}{l}41000000 \text { children aged under } 5 \text { are } \\
\text { overweight }\end{array}$ & $\begin{array}{l}\text { Needs of individuals and } \\
\text { families }\end{array}$ & $\begin{array}{l}\text { Multidisciplinary } \\
\text { integration }\end{array}$ & Transformative Action \\
\hline \multirow[t]{4}{*}{$\begin{array}{l}\text { Areas of } \\
\text { Practice }\end{array}$} & Academic discipline & $\begin{array}{l}\text { Collect data to understand } \\
\text { the incidence of obesity in } \\
\text { a location }\end{array}$ & $\begin{array}{l}\text { Analyse data and consider } \\
\text { contextual factors such as } \\
\text { physical activity rates } \\
\text { influencing obesity rates }\end{array}$ & $\begin{array}{l}\text { Deliver nutrition and } \\
\text { health education to parents } \\
\text { and analyse the impact on } \\
\text { food choices pre and post } \\
\text { intervention }\end{array}$ \\
\hline & Everyday living & $\begin{array}{l}\text { Develop information for } \\
\text { parents of under } 5 \text { 's } \\
\text { identifying poor and good } \\
\text { nutrition choices }\end{array}$ & $\begin{array}{l}\text { Encourage increased } \\
\text { physical activity in under } \\
5 \text { 's }\end{array}$ & $\begin{array}{l}\text { Advocate for healthy food } \\
\text { practices in grocery stores } \\
\text { eg. free fruit for under } 5 \text { 's }\end{array}$ \\
\hline & Curriculum area & $\begin{array}{l}\text { Incorporate nutrition } \\
\text { education in high school } \\
\text { classes }\end{array}$ & $\begin{array}{l}\text { Integrate content from a } \\
\text { range of knowledge bases } \\
\text { (e.g., HPE, science) }\end{array}$ & $\begin{array}{l}\text { Advocate for food literacy } \\
\text { subjects as core curriculum } \\
\text { for high school children }\end{array}$ \\
\hline & Society and policy & $\begin{array}{l}\text { Select and analyse a } \\
\text { national food guideline for } \\
\text { nutrition for under 5's }\end{array}$ & $\begin{array}{l}\text { Evaluate the national food } \\
\text { guidelines for early years } \\
\text { learning centres }\end{array}$ & $\begin{array}{l}\text { Influence policy as a Board } \\
\text { member on a government } \\
\text { committee }\end{array}$ \\
\hline
\end{tabular}


- $\quad$ poverty and inequalities

- demography (population growth, ageing, migration, urbanization)

- environmental degradation and climate change

- shocks and crises (economic and trade downturn, unemployment, conflicts and violence, disasters, disease outbreaks, hunger and food insecurity)

- development cooperation and financing for development

- technological innovation (food and water security, health, education, climate change and environment, data revolution)

These will be more likely to have positive impacts with collaboration and cooperation between countries, in addition to natural competition and innovation in the private sector. According to the United Nations Research Institute for Social Development (Dugarova \& Gülasan, 2017) alongside the six mega-trends that will significantly enhance the prospects for achievement of the agenda if they are intentionally managed, there are four actions for accelerating these trends:

- Building an evidence base to ensure efficacy of impact

- Enabling policy coherence

- Facilitating and leading collective action

- Heightening participation and political influence

These four factors can be enabled through two key forces: education and governance. With regard to education, it has the potential to be an enabler with such an influence that Pota (2016) for example, argues "education is the rock on which sustainable development is built". In terms of governance, that is how societies make decisions and take action, the effect is crucial to the extent that SDGs are likely to fail unless clear attention is given to addressing governance challenges crucial to their implementation. Taken together, education and governance are key enablers to achieving the SDG agenda. The potential for the home economics profession to contribute to shoring up the enablers must not be overlooked.

\section{BUILDING AN ACTION PLAN}

Home Economics Literacy brings together the Areas of practice and Essential dimensions of Home Economics and through this mechanism there is potential to accelerate the SDGs. The complexity of the sustainability challenges we face means we require a systemic approach if we are to create the change necessary for the future. To that end I have drawn upon the approach proffered by Birney (2014) expanding her proposed six strategies into an 8 Stage Action Plan (Fig. 2).

\section{ENABLERS AND INHIBITORS}

What are the inhibitors and enablers to home economics contributing to the SDG agenda? Taking a strengths-based approach to strategically operate is the most powerful mechanism to draw out the enablers and stifle inhibitors. A strength-based paradigm means there is a shift from problemsolving to identifying strengths and resources and setting up enabling conditions to support that further support that strength. Enablers targeting the strengths of the profession hence assist the acceleration of the SDG agenda when harnessed effectively and connected to The 8 Stage Action Plan.

\section{GROWTH MINDSET}

Certainly the profession is focused on the areas of concern to the SDGs. An analysis set out to provide a snapshot of the content of publications in the International Journal of Home Economics (IJHE) 2008-2014. This was achieved through a thematic content analysis of the fourteen issues (102 papers) of the Journal. Eight dominant themes emerged: life, family, social, time, people, work, families, society, need, home, individual, world, role, personal, community (Pendergast, 2017) revealing the interest of the profession is strongly connected to many of the areas of attention of the SDGs. Home economics has potential to play an important role in the acceleration and potential achievement of the SDGs.

TABLE IV. ENABLERS ANG INHIBITURS TO A STREGHTS-BASED APPROACH FOR HOME ECONOMICS TO ACCELERATE THE SDGs AGENDA

\begin{tabular}{|c|c|}
\hline Inhibitors (Challenges) & Enablers \\
\hline $\begin{array}{ll}\text { - } & \text { Evidence base - HELM Best practice } \\
\text { - } & \text { Reluctance to facilitate and lead collective action } \\
\text { - } & \text { Globally lumpy political influence } \\
\text { - } & \text { Resources - time, money } \\
\text { - } & \text { Voluntary base } \\
\text { - } & \text { Lack of willingness to collaborate with others } \\
\text { - } & \text { Fear of disruption of past strengths and status quo } \\
\text { - } & \text { Governance } \\
\text { - } & \text { Competition } \\
\text { - } & \text { Lack of risk-taking culture/conservatism } \\
\text { - } & \text { Lack of skillset for novel and adaptive mindset } \\
\text { - } & \text { Lack of skillset for virtual collaboration }\end{array}$ & $\begin{array}{l}\text { - } \quad \text { Philosophical intent } \\
\text { - } \quad \text { Focus on wellbeing_-social and emotional intelligence } \\
\text { - } \quad \text { Transdisciplinary } \\
\text { - } \quad \text { and Areas of practice } \\
\text { - } \quad \text { Global reach } \\
\text { - Revival ("Bring back home economics") } \\
\text { - Innovation and design mindset }\end{array}$ \\
\hline
\end{tabular}




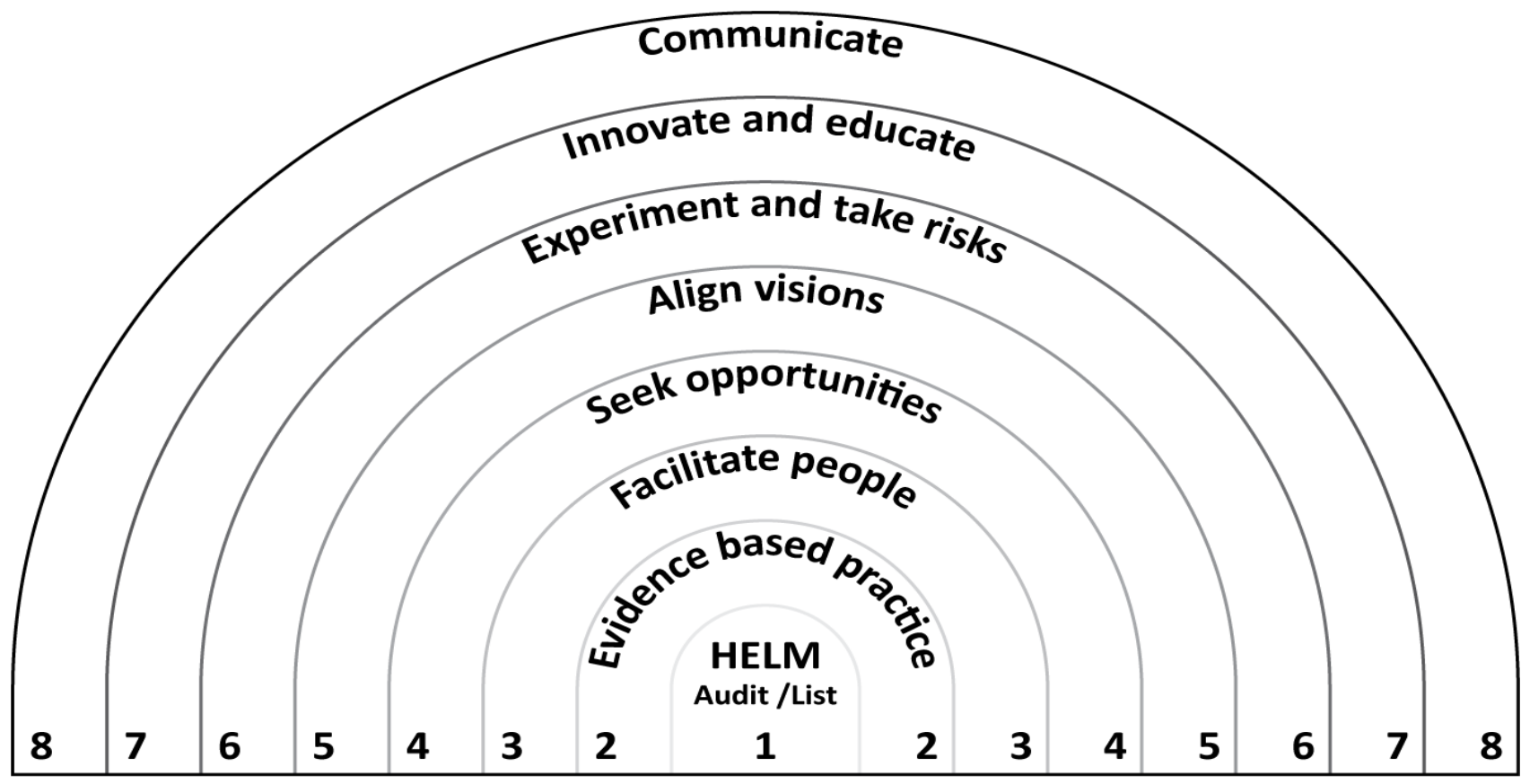

\begin{tabular}{|c|c|}
\hline Stage & ion \\
\hline 1 & $\begin{array}{l}\text { Audit the potential contribution of home economics to achieve the SDG goals and targets using the HELM and establish a priority list. } \\
\text { This might be at a global, local or individual level and is likely to be related to the SDGs identified by IFHE (2017) 1,3, 5, 6, 12 and/or } \\
\text { Pendergast (2017) } 2,3,4,5,12,17\end{array}$ \\
\hline 2 & $\begin{array}{l}\text { Build a culture of evidence-based practice elements for achieving Best Practice and efficacy for home economics in the SDG work (See } \\
\text { Pendergast, 2015) }\end{array}$ \\
\hline 3 & $\begin{array}{l}\text { Facilitate people convening and establishing coalitions for the selected SDG/s focus. Change begins and ends with people ready to lead } \\
\text { themselves and their organisations. It is essential to find the right people in the right organisations and form this coalition through } \\
\text { envisioning and developing innovation work-streams. This has the potential to set a strong foundation for its impact in future. }\end{array}$ \\
\hline 4 & $\begin{array}{l}\text { Find opportunities. Systems are complex and it is not always immediately evident where or when they might transform and so } \\
\text { searching for opportunities and acting opportunistically is important. Scanning what is going on in the world helps find windows of } \\
\text { opportunity and points of leverage. Taking a systemic approach means we need to analyse the landscape through mapping, and observe } \\
\text { and experience where these opportunities lie. Begin by using the audits to identify goals and targets relevant to home economics and } \\
\text { use these as the themes for focus. }\end{array}$ \\
\hline 5 & $\begin{array}{l}\text { Align visions to our living systems. Many of our actions do not feel as if they are helping us get close to solving the huge sustainability } \\
\text { challenges we face-issues like climate change. We often feel overwhelmed by the enormity of the challenges and locked into the } \\
\text { current way of doing things. Sustainability requires approaches that recognise that our social systems are part of the wider ecological } \\
\text { system in order to create visions and purposes that help to shift this perspective. This means radically reimagining how systems can be } \\
\text { transformed and letting go of the prevailing perspectives that have built current institutions and economy. }\end{array}$ \\
\hline 6 & $\begin{array}{l}\text { Experiment and take risks. Change will not happen unless we create something new. In nature, our living systems change through } \\
\text { multiple experiments that evolve and shift the world around us. We need to be risk takers and be prepared to try and to fail and to have } \\
\text { a growth mindset. This needs to take place with the coalition bringing strengths to the facets of the SDGs }\end{array}$ \\
\hline 7 & $\begin{array}{l}\text { Create innovation and learning platforms. We spend a lot of time creating new innovations or piloting projects but this will not create a } \\
\text { system shift. We need to create platforms that support innovation and learning so we start to accelerate the scale and reach of change. } \\
\text { Nike, with USAid and Nasa, have created such a platform called Launch } 2020 \text {, which seeks to accelerate a revolution in sustainable } \\
\text { materials through utilising networks, strategies and resources for change. }\end{array}$ \\
\hline 8 & $\begin{array}{l}\text { Communicate a coherent and engaging story. Environmental and social NGO campaigns tend to focus on what is going wrong by } \\
\text { looking to change the policies and parameters of a particular system. To actively open up permission to create change, we need to } \\
\text { support the consolidation of change into new narratives for society and come together to influence the wider cultural conversation. This } \\
\text { will influence how we operate in systems and change the assumptions about systems. }\end{array}$ \\
\hline
\end{tabular}

Fig. 2.The 8 Stage Action Plan 


\section{REFERENCES}

[1] United Nations General Assembly. (2000). United Nations millennium declaration. United Nations General Assembly.

[2] United Nations. (2015). Transforming our world: the 2030 Agenda for Sustainable Development. Washington: United Nations

[3] International Federation for Home Economics (IFHE). (2008). IFHE Position Statement - Home economics in the 21st Century. Bonn, Germany: Author.

[4] The Guardian (2015). Sustainable development goals: changing the world in 17 steps - interactive Accessed 3 March 2017 https://www.theguardian.com/global-development/nginteractive/2015/jan/19/sustainable-development-goals-changing-world17-steps-interactive

[5] Pendergast, D. (2017). Home economics literacy: What in the world are we saying? [online]. International Journal of Home Economics, Vol. 10, No. 1, 2017: 141-150.

[6] International Federation for Home Economics (IFHE). (2017). Draft IFHE Position Statements on the UN Sustainable Development Goals, Unpublished Council paper

[7] International Federation for Home Economics (IFHE), (2015). Press Release: World Home Economics Day 21 March 2015. Home Economics literacy: Skills for families and consumers. IFHE: Bonn.

[8] Pendergast, D. (2015). HELM - Home Economics Literacy Model - A vision for the field. Victorian Journal of Home Economics, 54(1), 2-6.

Smith, M. G. (2009). Food or nutrition literacy? What concept should guide Home Economics education? International Journal of Home Economics, 2(1), 48-64

[9] Nutbeam, D. (2000). Health literacy as a public health goal: A challenge for contemporary health education and communication strategies into the $21 \mathrm{st}$ century. Health Promotion International, 15(3), 259-267.
[10] Freebody, P., \& Luke, A. (1990). 'Literacies' Programs: debates and demands in cultural context. Prospect, 5, 7-16.

[11] Maggio, A., Van Criekinge, T., \& Malingreau, J. P. (2015). Global Food Security 2030: Assessing Trends with a View to Guiding Future EU Policies. Brussels: Joint Research Centre, European Commission.

[12] Food and Agriculture Organization of the United Nations, International Fund for Agricultural Development and World Food Programme (2016). The State of Food and Agriculture: Climate Change, Agriculture and Food Security. Rome.

[13] Dugarova, E., \& Gülasan, N. (2017). Global trends: Challenges and Opportunities in the Implementation of the Sustainable Development Goals. United Nations Development Programme and United Nations Research Institute for Social Development. $\begin{array}{llll}\text { Accessed } & 1 & \text { March } & 2017\end{array}$ http://www.undp.org/content/undp/en/home/librarypage/sustaina ble-development-goals/global-trends--challenges-andopportunities-in-the-implementatio.html

[14] Pota, V. (2016). Sustainable development goals are failing because we don't care enough about education. Retrieved from http://vikaspota.com/2016/09/08/sustainable-developmentgoals-are-failing-because-we-dont-care-enough-abouteducation/

[15] Birney, A. (2014). Six strategies for creating system change for a sustainable future. Accessed 10 August 2017.https://www.theguardian.com/sustainablebusiness/blog/six-strategies-systems-change-sustainable-future 